\title{
Siew New Disease Reports \\ First report of natural occurence of Papaya leaf crumple virus on soyabean in India
}

\author{
M. Jaidi ${ }^{1}$, A. Srivastava ${ }^{1}$, S. Kumar ${ }^{1}$, S.K. Raj $^{1 *}$ and R. Singh ${ }^{2}$ \\ ${ }^{1}$ Plant Molecular Virology Laboratory, CSIR-National Botanical Research Institute, Lucknow-226001 (U.P.), India;; ${ }^{2}$ Amity \\ Institute of Biotechnology, Amity University Lucknow Campus, Gomti Nagar extension, Lucknow-226010, (U.P.), India
}

*E-mail: skraj2@rediffmail.com

Received: 22 Jul 2015. Published: 31 Oct 2015.

Soybean (Glycine max, family Fabaceae) is a most important nutrient crop. It is native to East Asia and is grown widely as a pulse rich in protein, and also has numerous other uses. Symptoms of leaf crumple disease at Lalitpur $\left(24.6^{\circ} \mathrm{N}, 78.4^{\circ} \mathrm{E}\right)$, India and yellow mosaic disease at Lucknow $\left(26.8^{\circ} \mathrm{N}\right.$, $80.9^{\circ} \mathrm{E}$ ), India, were noticed on a number of soybean plants in 2013. The naturally infected soybean plants exhibited yellow mosaic on leaves (Fig. 1a) and leaf crumpling and distortion symptoms (Fig. 1b). Severely infected plants were stunted and bore less number of flowers and pods as compared to the healthy ones. Based on leaf crumple and yellow mosaic symptoms, begomovirus infection was suspected. Twenty-two leaf samples of infected soybean plants were collected from each location and total DNA was isolated using a plant genomic DNA isolation kit (Sigma, USA). The PCRs were performed with begomovirus degenerate primers (Rojas $e t$ al., 1993) which resulted in expected size amplicon of $\sim 1.2 \mathrm{~kb}$ from $16 / 22$ samples of yellow mosaic diseased plants collected from Lucknow and 12/22 samples of leaf crumple diseased plants collected from Lalitpur, but not from the healthy samples (Fig. 2). This indicated the presence of begomovirus in the soybean plants that had been sampled.

To identify the complete genome sequence of these begomoviruses, total DNAs isolated from a representative leaf sample exhibiting yellow mosaic and leaf crumple symptoms were subjected separately to rolling circle amplification (RCA, TempliPhi kit, GE Healthcare, USA) followed by digestion with EcoRI, BamHI, HindIII, Sal1, XhoI, PstI and XbaI enzymes. Electrophoresis of products digested only with BamHI resulted in a DNA fragment of $\sim 2.7 \mathrm{~kb}$ in both the samples. The products obtained $\sim 2.7 \mathrm{~kb}$ were cloned separately into the pCAMBIA1300 vector, sequenced and deposited in GenBank with Accession Nos. KR052025 (MJS-1 isolate from yellow mosaic sample of Lucknow) and KR071789 (MJS-2 isolate from crumpled leaf sample of Lalitpur). The sequence analyses of MJS-1 and MJS-2 isolates showed the typical genome of begomovirus containing six open reading frames (V2 and V1 in sense strand and C1-C4 in antisense strand). BLASTn analysis of nucleotide sequence of begomovirus isolate MJS-1 under study showed 98-99\% nucleotide sequence identity with Mungbean yellow mosaic India virus (MYMIV) isolates of Vigna unguiculata (DQ389153) and of G. $\max$ (EU523045, KC852204) reported from India. However, begomovirus isolate MJS-2 shared 94-97\% identity with isolates of Papaya leaf crumple virus (PaLCrV) from Carica papaya (HM140367, HM140368, HM140369) and Solanum nigrum
(KJ028210) both from India, and C. papaya (HE580236) from Pakistan. During phylogenetic analysis by MEGA v6.0 program (Tamura et al., 2013) using nucleotide sequences of MYMIV and PaLCrV and some other begomoviruses available in GenBank database, MJS-1 and MJS-2 isolates showed close relationships with MYMIV and PaLCrV isolates, respectively (Fig. 3), hence the begomovirus isolated from soybean were identified as MYMIV and PaLCrV. A literature survey revealed the natural occurrence of MYMIV (Girish and Usha 2005), Tomato leaf curl Karnatka virus (Raj et al., 2006a) and Cotton leaf curl Kokhran virus (Raj et al., 2006b) on soybean in India. The existence of PaLCrV is reported on $C$. papaya (Singh-Pant et al., 2012), S. nigrum and Andrographis paniculata from India. However, this is the first report of natural occurrence of $\mathrm{PaLCrV}$ in soybean from India.

\section{References}

Rojas MR, Gilbertson RL, Russell DR, Maxwell DP, 1993. Use of degenerate primers in the polymerase chain reaction to detect whiteflytransmitted geminiviruses. Plant Disease 77, 340-347. http://dx.doi.org/10.1094/PD-77-0340

Girish KR, Usha R, 2005. Molecular characterization of two soybeaninfecting begomoviruses from India and evidence for recombination among legume-infecting begomoviruses from South-East Asia. Virus Research 108, 167-176. http://dx.doi.org/10.1016/j.virusres.2004.09.006

Raj SK, Khan MS, Snehi SK, Singh HB, 2006a. First report of Tomato leaf curl Karnatka virus infecting soybean in India. Plant Pathology 55, 817. http://dx.doi.org/10.1111/j.1365-3059.2006.01473.x

Raj SK, Khan MS, Snehi SK, Srivastava S, Singh HB, 2006b. A yellow mosaic disease of soybean in northern India is caused by Cotton leaf curl Kokhran virus. Plant Disease 90, 975.

http://dx.doi.org/10.1094/PD-90-0975C

Singh-Pant P, Pant P, Mukherjee SK, Mazumdar-Leighton S, 2012. Spatial and temporal diversity of begomoviral complexes in papayas with leaf curl disease. Archives of Virology 157, 1217-1232.

http://dx.doi.org/10.1094/PD-90-0975C

Tamura K, Stecher G, Peterson D, Filipski A, Kumar S, 2013. MEGA6: Molecular Evolutionary Genetics Analysis version 6.0. Molecular Biology and Evolution 30, 2725-2729. http://dx.doi.org/10.1093/molbev/mst197

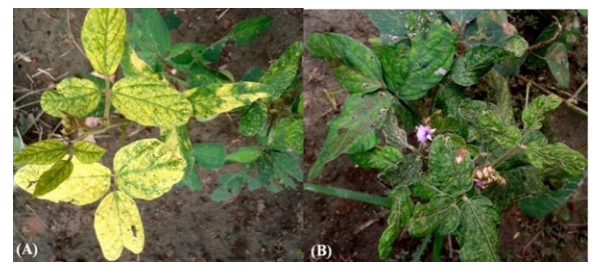

Figure 1

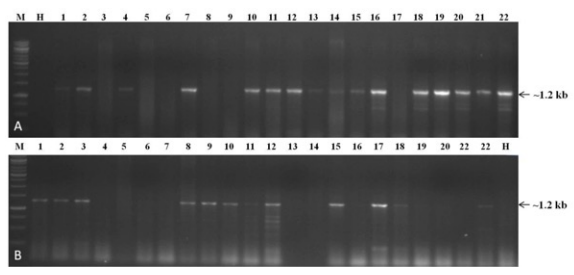

Figure 2

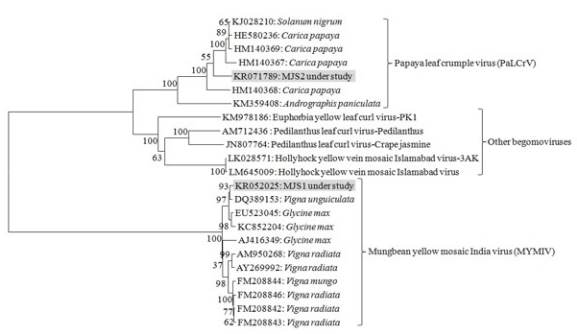

Figure 3

To cite this report: Jaidi M, Srivastava A, Kumar S, Raj SK, Singh R, 2015. First report of natural occurence of Papaya leaf crumple virus on soyabean in India. New Disease Reports 32, 15. http://dx.doi.org/10.5197/j.2044-0588.2015.032.015

(c) 2015 The Authors

This report was published on-line at www.ndrs.org.uk where high quality versions of the figures can be found. 